\title{
NUTRITIONAL ADEQUACY AND ORAL NUTRITIONAL SUPPLEMENTATION IN OLDER COMMUNITY-DWELLING ADULTS
}

\author{
L. McKeever ${ }^{1}$, I.C. Farrar ${ }^{2}$, S. Sulo, J. Partridge 3 , P. Sheean ${ }^{4}$, M. Fitzgibbon ${ }^{5,6}$
}

\begin{abstract}
Background: Older adults (65 years and older) comprise a high-risk group that are susceptible to the development of malnutrition. Dietary intake and diet quality represent key modifiable risk factors to help prevent and to treat declines in nutrition status, with oral nutritional supplements (ONS) often being a cost-effective therapy for many to increase protein and caloric intake. The DETERMINE Checklist offers a series of questions capable of mapping the initial landscape of contextual factors that influence the dietary patterns of the at-risk populations. Objectives: To examine independent predictors of inadequate dietary intake and poor diet quality amongst a multi-ethnic sample of urban community-dwelling older adults in an effort to identify target groups of participants that could benefit most from an ONS intervention. Design: Cross-sectional. Participants: Chicago, Illinois, United States urban residents greater than 55 years of age who self-reported to be non-Hispanic White, non-Hispanic Black, or Hispanic. Methods: Telephone surveys were conducted to obtain basic demographic information. The DETERMINE Checklist was administered to (1) characterize participants' nutritional risk, and (2) identify participants with inadequate intake and/or poor diet quality. Predictors of inadequate intake, defined as any participant who reported either to eat less than two meals per day and/or poor diet quality, defined as any participant who reported to eat few fruits, vegetables or dairy were used to identify groups of participants who could benefit most from ONS consumption. Mantel-Hanzel chi square, Breslow-day tests, and logistic regressions were conducted. Results: 1001 ethnically diverse participants were interviewed (37\% non-Hispanic White, 37\% non-Hispanic Black, and 26\% Hispanic). Respondents were predominantly female $(69 \%)$ with a mean age of $66.9( \pm 6.4)$ years. The majority were found to be at either moderate or high nutrition risk $(78.7 \%)$. Domains of the DETERMINE Checklist that predicted either inadequate dietary intake or poor diet quality included social isolation, lower levels of educational attainment, food insecurity, limitations in activities of daily living (ADL), polypharmacy, or three or more alcoholic drinks per day. Of the participants who met the criteria as those who would benefit from ONS, less than $50 \%$ had reported consuming ONS in the past six months. Conclusion: Older communitydwelling adults living in an urban setting, especially those with social isolation, lower levels of education, food insecurity, limitations with ADLs, polypharmacy, and those reporting heavy alcohol intake represent a population who could benefit from consuming ONS. Efforts should be made towards further understanding these contextual factors and providing nutrition education along with an ONS intervention that could be beneficial to supplement dietary inadequacies in this population.
\end{abstract}

Key words: Nutrition risk, community nutrition, older adults, oral nutritional supplement, DETERMINE Checklist.

\section{Introduction}

Older adults (65 years and older) comprise a highrisk group that are susceptible to the development of malnutrition. This can occur due to decreased macronutrient intake, poor diet quality (1), mental

\footnotetext{
1. Department of Kinesiology and Nutrition, College of Applied Health Sciences, University of Illinois at Chicago, Chicago, IL, USA; 2. Survey Research Laboratory, University of Illinois at Chicago, Chicago, IL; USA; 3. Abbott Nutrition Research \& Development, Columbus, OH, USA; 4. Marcella Niehoff School of Nursing, Loyola University, Chicago, IL, USA; 5. Institute for Health Research and Policy, University of Illinois at Chicago, Chicago, IL, USA; 6. Department of Pediatrics, College of Medicine, University of Illinois at Chicago, Chicago, IL, USA
}

Corresponding Author: Liam McKeever, PhD, RDN, University of Illinois at Chicago, Department of Kinesiology and Nutrition, College of Applied Health Sciences, 1919 W. Taylor St, Applied Health Sciences Building, Room 633, Chicago, IL 60612, Email: wmckee2@uic.edu, Phone: 773-263-2492

illness $(2,3)$ impaired mastication $(3,4)$ polypharmacy (4), social isolation $(5,6)$, poverty $(1)$, and declines in activities of daily living (ADL) $(4,7,8)$. Preventing or treating malnutrition in this population is important, as it is associated with increased mortality (9), hospital readmission $(10,11)$, unplanned weight loss (1), increased fractures $(12,13)$, and loss of independence (14). Dietary intake and diet quality represent key modifiable risk factors to help prevent and to treat declines in nutrition status, with oral nutritional supplements (ONS) often being a cost-effective therapy for many to increase protein and caloric intake. In fact, when ONS is used independently and in combination with other nutrition interventions (e.g., education, dietary counseling, etc.) among community-dwelling adults, it may result in overall cost savings due to improving health outcomes of at-risk for malnutrition patients (15-17). 
In 1993, the Nutrition Screening Initiative (NSI) developed the DETERMINE Checklist, a nutrition screening tool of 10 questions designed to identify older adult patients who would benefit from more in-depth nutrition assessment (1). This checklist was created primarily to facilitate the education of patients on the importance of nutrition as well as to inform clinicians of the unique dietary needs of older adults. While the DETERMINE Checklist was not designed as a standalone screening tool, its 10 questions cover a broad range of scenarios that characterize the unique challenges of the aging population. Of these 10 questions, 1 relates to inadequate intake, identifying patients who 'eat fewer than 2 meals per day.' One relates to poor diet quality, detecting patients who eat 'few fruits, vegetables, or milk products,' while the remaining 8 questions categorize possible causes for inadequate intake or poor diet quality.

To date, the literature exploring malnutrition in the United States (USA) within community settings is limited and few studies have specifically examined the independent root causes of modifiable malnutrition risk factors. Therefore, the objective of this study was to use the DETERMINE Checklist to: (1) examine the independent predictors of inadequate intake and poor diet quality amongst a multi-ethnic sample of older urban community-dwelling adults, and (2) to use those predictors to identify target groups (Predictor Groups) of participants that could benefit most from ONS intervention.

\section{Methods}

This cross-sectional study was conducted in community-dwelling Chicago, Illinois (USA) residents greater than 55 years of age. Respondent information was collected via a telephone survey, which was created by a multidisciplinary team of researchers in collaboration with the Survey Research Laboratory of the University of Illinois at Chicago (SRL). The telephone interviews were conducted by the Interviewing Service of America (ISA).

Interviewer Training: Twenty-nine interviewers from ISA underwent a rigorous 24-hour general training in telephone interviewing skills. They were then trained specifically on the components of the study survey by expert personnel. This included orientation to the background and purpose of the study, training in each survey question, and practice interviews.

\section{Field Procedures}

This study was conducted over 4 months. Four sample frames were used; two random digit dial (landline and cell) and two listed (landline and cell). The two listed sample frames were targeted to reach participants within the selected age range and race/ethnicity distributions. Potential participants were called up to 6 times before determining them unreachable. Computer Assisted
Telephone Interviewing (CATI) software was used to administer the survey. Interviews were conducted in English and Spanish on weekends and weekday evenings. Respondents were told the interview would last approximately 20 minutes and they would be paid $\$ 10$ for their participation if they provided their mailing address.

\section{Participants}

Eligible participants for this study were any person residing within the City of Chicago, Illinois, USA who used a landline or a cell phone with a Chicago area code. To be included in the survey, participants had to self-report their race/ethnicity as non-Hispanic White, non-Hispanic Black, or Hispanic; speak either English or Spanish; be 55 years of age or older; and be willing to participate in the study.

\section{The Survey}

The goal of the survey was to characterize nutritional risk, specifically seeking information regarding ONS usage. Components of the survey included in the analysis were basic sociodemographic information (i.e., gender, age, height, weight, education, insurance status), administration of the DETERMINE Checklist, and recent ONS usage.

\section{Nutritional Risk}

The DETERMINE Checklist is a list of 10 yes / no statements surveying various predetermined risk factors related to malnutrition risk in the older adults. Originally, the DETERMINE Checklist was tested in adults greater than 70 years of age (1), but has since been used and validated in adults as young as 60 years (18, 19). Usually, a score ranging from 0 to 21 is generated from these yes/no comments on nutrition risk in general: no nutritional risk (0-2), moderate nutritional risk (3-5) or high nutritional risk (6 or more). The current study abandons analysis of the score itself, but makes use of the questions as system of independent and dependent variables to predict groups that might benefit most from ONS. Figure 1 lists the DETERMINE Checklist questions and details the proxy terms used to describe the study variables. For the purpose of this study, a participant with 'Inadequate Intake' was defined as anyone who answered 'yes' to the DETERMINE Checklist item for eating fewer than 2 meals per day. A participant with 'Poor Diet Quality' was defined as anyone who answered 'yes' to the DETERMINE Checklist item for eating few fruits, vegetables, or milk products. These are simple, yet efficient screening questions that directly address the root sources of malnutrition. 


\section{Figure 1}

The NSI DETERMINE Checklist and Proxy Terms for Each Item

\begin{tabular}{|c|c|}
\hline \multicolumn{2}{|c|}{ Nutrition Screening Initiative (NSI) DETERMINE Checklist } \\
\hline Question Asked & Proxy Meaning \\
\hline $\begin{array}{l}\text { I have an illness of condition that made me change the kind } \\
\text { and / or amount of food I eat }\end{array}$ & Illness-induced diet change \\
\hline I eat fewer than two meals per day & Inadequate intake \\
\hline I eat few fruits vegetables or milk products & Poor diet quality \\
\hline $\begin{array}{l}\text { I have three or more drinks of beer, liquor or wine almost every } \\
\text { day }\end{array}$ & $3+$ drinks per day \\
\hline I have tooth or mouth problems that make it hard for me to eat & Dentition/mouth issues \\
\hline I don't always have enough money to buy the food I need & Food insecurity \\
\hline I eat alone most of the time & Social isolation \\
\hline $\begin{array}{r}\text { I take three or more different prescribed or over-the-counter } \\
\text { drugs a day }\end{array}$ & Polypharmacy \\
\hline $\begin{array}{r}\text { Without wanting to, I have lost or gained } 10 \text { pounds in the last } \\
\text { six months }\end{array}$ & Unplanned weight change \\
\hline $\begin{array}{r}\text { I am not always physically able to shop, cook and / or feed } \\
\text { myself }\end{array}$ & ADL issues* \\
\hline
\end{tabular}

${ }^{*} \mathrm{ADL}=$ Activities of Daily Living

\section{ONS}

ONS was defined for the participants as liquid beverages found in the pharmacy section of their grocery store or in special sections of their pharmacy that are consumed in addition to food when diet alone cannot fully provide calorie, protein, and other nutrient needs. Participants were asked whether they had consumed ONS in the past six months.

\section{Outcome Variables}

The analysis centered on identifying groups of participants who had increased odds of inadequate intake and/or poor diet quality. Potential groups explored were participants who answered 'yes' to any of the remaining 8 domains of the DETERMINE Checklist, as well as the standard sociodemographic variables. Groups with increased odds of either inadequate nutritional intake and/or poor diet quality were labeled Predictor Groups as they were predictive of those two variables and constituted groups of participants who could benefit most from ONS consumption.

\section{Statistical Analysis}

Utilizing basic demographic information from the survey, and data from the DETERMINE Checklist, our analysis centered on identifying groups of participants who had increased odds of inadequate dietary intake and/or poor diet quality. Groups with increased odds of either inadequate intake and/or poor diet quality were labeled Predictor Groups as they were predictive of those two variables and constituted groups of participants who could benefit most from ONS consumption. Descriptive statistics were conducted to assess differences stratified by gender and race/ethnicity. Predictors of inadequate intake and poor diet quality were explored using MantelHanzel chi square tests and logistic regression modeling. Potential predictors explored included the 8 other components of the DETERMINE Checklist as well as basic sociodemographic variables. Breslow-Day tests were then used to explore effect modification amongst the potential predictors. Model one explored predictors of inadequate intake and model two explored predictors of poor diet quality. Regression diagnostics were run to assess collinearity amongst variables and manual backwards elimination with an alpha cut-point of $<0.05$ being used to derive the final models. All statistical analyses were run in SAS 9.4.

\section{Results}

The ISA database contained 64,475 relevant phone numbers. Ninety percent of these numbers were unusable $(n=57,381)$ because they were no longer working $(42 \% ; \mathrm{n}=27,022)$, the participant did not answer $(27 \%$, $\mathrm{n}=17,427)$, they went to voicemail $(19 \%, \mathrm{n}=11,922)$, or the participant was no longer living in Chicago $(2 \%, \mathrm{n}=1,010)$. Of the 7064 remaining numbers, 1001 participants were found eligible, able and willing to complete the interview. Based on the ratio of participants eligible, able and willing to complete the survey and patients known to be eligible, but unwilling or unable, our response rate was $85.8 \%(n=1001 / 1165)$. Based on the sum of eligibility estimates from the larger unreachable sample and the known eligible, a more conservative response rate of $7.7 \%(n=1001 / 12,948)$ was calculated. The mean age of respondents was $66.9( \pm 6.4)$ years. Respondents were predominantly female $(69 \%)$ with fairly equal distribution by race/ethnicity [nonHispanic White $(37 \%)$, non-Hispanic Black $(37 \%)$ and Hispanic $(26 \%)]$. Education attainment was high overall with approximately $60 \%$ of participants reporting they attended 'at least some college.' College attendance was particularly low, however, amongst Hispanics (28\%) as compared to non-Hispanic Blacks $(60 \%)$ and nonHispanic Whites (82\%). Over 73\% of the population was either overweight or obese. Very few participants in our sample were underweight $(3 \%)$ as defined by $\mathrm{BMI}<18.5 \mathrm{~kg} / \mathrm{m} 2$. The DETERMINE Checklist found $28.6 \%$ of participants to be at moderate nutrition risk and $50.1 \%$ of participants to be at high nutrition risk. Frequency tables for sociodemographic characteristics and DETERMINE Checklist risk factors stratified by oral intake status and diet quality are presented in Table 1. Inadequate dietary intake and poor diet quality were more common in participants with illness-induced diet changes, poor dentition and oral disease, food insecurity, social isolation, polypharmacy, limitations in ADL, and 
Table 1

Sociodemographic and NSI DETERMINE Risk Factor Characteristics Stratified by Oral Intake and Diet Quality

\begin{tabular}{|c|c|c|c|c|c|c|c|}
\hline & \multirow[b]{2}{*}{ Total N=1001 } & \multicolumn{3}{|c|}{ Inadequate Intake } & \multicolumn{3}{|c|}{ Poor Diet Quality } \\
\hline & & Yes $N=274$ & No $N=722$ & $\mathbf{P}^{\mathbf{a}}$ & Yes $N=476$ & No $=520$ & $\mathbf{P}^{\mathbf{a}}$ \\
\hline Age & & & & 0.151 & & & 0.277 \\
\hline $55-67$ years & 497 & 126 & 367 & & 228 & 265 & \\
\hline$\geq 67$ years & 455 & 135 & 319 & & 226 & 228 & \\
\hline Gender & & & & 0.433 & & & 0.021 \\
\hline Female & 694 & 185 & 506 & & 314 & 378 & \\
\hline Male & 307 & 89 & 216 & & 162 & 142 & \\
\hline Race/Ethnicity & & & & $<0.0001$ & & & $<0.0001$ \\
\hline White & 373 & 63 & 308 & & 130 & 243 & \\
\hline Black & 369 & 117 & 249 & & 189 & 177 & \\
\hline Hispanic & 259 & 94 & 165 & & 157 & 100 & \\
\hline Body mass index Category & & & & 0.067 & & & 0.014 \\
\hline Underweight & 26 & 12 & 14 & & 18 & 8 & \\
\hline Normal weight & 242 & 57 & 184 & & 96 & 143 & \\
\hline Overweight & 326 & 92 & 233 & & 154 & 171 & \\
\hline Class I Obese & 202 & 52 & 149 & & 96 & 105 & \\
\hline Class II Obese & 81 & 19 & 62 & & 44 & 37 & \\
\hline Class III Obese & 124 & 42 & 80 & & 68 & 56 & \\
\hline Education & & & & $<0.0001$ & & & $<0.0001$ \\
\hline Attended college & 595 & 114 & 477 & & 226 & 368 & \\
\hline High school or less & 398 & 155 & 242 & & 244 & 150 & \\
\hline Insurance & & & & 0.012 & & & 0.147 \\
\hline Yes & 918 & 242 & 671 & & 428 & 487 & \\
\hline No & 69 & 28 & 41 & & 38 & 30 & \\
\hline Illness-induced diet change & & & & 0.036 & & & 0.027 \\
\hline Yes & 427 & 131 & 294 & & 221 & 205 & \\
\hline No & 569 & 141 & 426 & & 253 & 312 & \\
\hline $3+$ drinks per day & & & & 0.163 & & & 0.172 \\
\hline Yes & 48 & 9 & 39 & & 27 & 20 & \\
\hline No & 952 & 265 & 682 & & 448 & 500 & \\
\hline Dentition/mouth issues & & & & $<0.0001$ & & & 0.003 \\
\hline Yes & 130 & 59 & 70 & & 78 & 52 & \\
\hline No & 870 & 215 & 651 & & 398 & 468 & \\
\hline Food insecurity & & & & $<0.0001$ & & & $<0.0001$ \\
\hline Yes & 298 & 124 & 174 & & 186 & 110 & \\
\hline No & 698 & 149 & 545 & & 288 & 408 & \\
\hline Social isolation & & & & $<0.0001$ & & & 0.040 \\
\hline Yes & 481 & 160 & 317 & & 245 & 235 & \\
\hline No & 516 & 112 & 403 & & 228 & 284 & \\
\hline Polypharmacy & & & & 0.032 & & & 0.057 \\
\hline Yes & 559 & 168 & 390 & & 280 & 276 & \\
\hline No & 438 & 104 & 330 & & 193 & 243 & \\
\hline Unplanned weight change & & & & $<0.0001$ & & & 0.083 \\
\hline Yes & 317 & 112 & 202 & & 164 & 153 & \\
\hline No & 675 & 155 & 518 & & 307 & 363 & \\
\hline $\mathrm{ADL}^{\mathrm{b}}$ issues & & & & $<0.0001$ & & & $<0.0001$ \\
\hline Yes & 207 & 88 & 118 & & 134 & 72 & \\
\hline No & 789 & 184 & 601 & & 339 & 446 & \\
\hline $\mathrm{ONS}^{\mathrm{c}}$ in past 6 months & & & & 0.172 & & & 0.717 \\
\hline Yes & 114 & 37 & 76 & & 56 & 58 & \\
\hline No & 882 & 234 & 644 & & 415 & 462 & \\
\hline
\end{tabular}


Table 2

Crude and Adjusted Odds Ratios (OR) for Logistic Regression Models predicting Inadequate Intake and Poor Diet Quality

\begin{tabular}{|c|c|c|c|c|}
\hline \multirow[b]{2}{*}{ Characteristic } & \multicolumn{2}{|c|}{ Models Predicting Inadequate Intake } & \multicolumn{2}{|c|}{ Models Predicting Poor Diet Quality } \\
\hline & $\begin{array}{l}\text { Crude OR for Inadequate } \\
\text { intake }(95 \% \mathrm{CI})\end{array}$ & $\begin{array}{c}\text { Adjusted OR for Inadequate } \\
\text { Intaket }(95 \% \text { CI) }\end{array}$ & $\begin{array}{l}\text { Crude OR for Poor Diet Qualityt+ } \\
\text { (95\% CI) }\end{array}$ & $\begin{array}{l}\text { Adjusted OR for Poor Diet Quality } \\
\text { (95\% (CI) }\end{array}$ \\
\hline \multicolumn{5}{|l|}{ Median age } \\
\hline $\begin{array}{l}\geq 67 \\
<67\end{array}$ & $\begin{array}{l}1.23(0.93,1.64) \\
\text { ref }\end{array}$ & - & $\begin{array}{c}1.15(0.89,1.49) \\
\text { ref }\end{array}$ & - \\
\hline \multicolumn{5}{|l|}{ Gender } \\
\hline $\begin{array}{l}\text { Male } \\
\text { Female }\end{array}$ & $\begin{array}{c}\text { ref } \\
0.89(0.66,1.20)\end{array}$ & - & $\begin{array}{c}\text { ref } \\
0.73(0.56,0.95)^{*}\end{array}$ & Varies by Education Status \\
\hline \multicolumn{5}{|l|}{ Race/Ethnicity } \\
\hline $\begin{array}{l}\text { Non-Hispanic White } \\
\text { Non-White } \\
\text { Black } \\
\text { Hispanic }\end{array}$ & $\begin{array}{c}\text { ref } \\
2.49(1.81,3.42)^{* *} \\
2.30(1.62,3.26)^{\star *} \\
2.79(1.92,4.04)^{\star *}\end{array}$ & $\begin{array}{l}\text { Varies by level of Education and } \\
\text { ADL Issues }\end{array}$ & $\begin{array}{c}\text { ref } \\
2.34(1.79,3.04)^{* *} \\
2.00(1.49,2.68)^{* *} \\
2.94(2.11,4.08)^{* *}\end{array}$ & $\begin{array}{c}\text { White Vs Other No ADL Issues } \\
0.54(0.39,0.75)^{*} \\
\text { Black Vs White No ADL Issues } \\
1.64(1.15,2.33)^{*} \\
\text { Hispanic Vs White No ADL Issues } \\
\text { 2.32(1.51, 3.56) } \\
\text { *OR's for effect of race amongst } \\
\text { subjects with ADL Issues insignifican }\end{array}$ \\
\hline \multicolumn{5}{|l|}{ BMIa Category } \\
\hline $\begin{array}{l}\text { Underweight } \\
\text { Normal } \\
\text { Overweight } \\
\text { Class I Obese } \\
\text { Class II Obese } \\
\text { Class III Obese }\end{array}$ & $\begin{array}{c}2.77(1.21,6.32)^{*} \\
\text { ref } \\
1.28(0.87,1.87) \\
1.13(0.73,1.74) \\
0.99(0.55,1.79) \\
1.70(1.05,2.73)^{*}\end{array}$ & - & $\begin{array}{c}3.35(1.40,8.01)^{*} \\
\text { ref } \\
1.34(0.96,1.88) \\
1.36(0.93,1.99) \\
1.77(1.07,2.94)^{*} \\
1.81(1.17,2.80)^{*}\end{array}$ & - \\
\hline $\begin{array}{l}\text { Median Education Level } \\
\text { Attended College } \\
\text { High School or Less }\end{array}$ & $\begin{array}{l}0.37(0.28,0.50)^{\star *} \\
\text { ref }\end{array}$ & $\begin{array}{c}\text { Amongst Whites } \\
0.22(0.12,0.42)^{* *} \\
\text { Amongst Blacks } \\
0.72(0.46,1.16) \\
\text { Amongst Hispanics } \\
0.54(0.28,1.03)\end{array}$ & $\begin{array}{l}0.38(0.29,0.49)^{\star *} \\
\text { ref }\end{array}$ & $\begin{array}{c}\text { Amongst Females } \\
0.66(0.47,0.94)^{*} \\
\text { Amongst Males } \\
0.30(0.17,0.52)^{\star *}\end{array}$ \\
\hline \multicolumn{5}{|l|}{ Insurance } \\
\hline $\begin{array}{l}\text { Yes } \\
\text { No }\end{array}$ & $\begin{array}{c}\text { ref } \\
1.89(1.15,3.13)^{*}\end{array}$ & - & $\begin{array}{c}\text { ref } \\
1.44(0.88,2.37)\end{array}$ & - \\
\hline \multicolumn{5}{|l|}{ Illness-induced diet change } \\
\hline $\begin{array}{l}\text { Yes } \\
\text { No }\end{array}$ & $\begin{array}{c}1.35(1.02,1.79)^{*} \\
\text { ref }\end{array}$ & - & $\begin{array}{c}1.33(1.03,1.71)^{*} \\
\text { ref }\end{array}$ & - \\
\hline \multicolumn{5}{|l|}{ 3+ Drinks per day } \\
\hline $\begin{array}{l}3+\text { drinks per day } \\
<3 \text { drinks per day }\end{array}$ & $\begin{array}{l}0.59(0.28,1.24) \\
\text { ref }\end{array}$ & - & $\begin{array}{c}1.51(0.83,2.72) \\
\text { ref }\end{array}$ & $\begin{array}{l}2.16(1.144 .09)^{*} \\
\text { ref }\end{array}$ \\
\hline \multicolumn{5}{|l|}{ Dentition/Mouth Problems } \\
\hline $\begin{array}{l}\text { Yes } \\
\text { No }\end{array}$ & $\begin{array}{c}2.55(1.77,3.73)^{\star *} \\
\text { ref }\end{array}$ & - & $\begin{array}{c}1.76(1.21,2.57)^{*} \\
\text { ref }\end{array}$ & - \\
\hline \multicolumn{5}{|l|}{ Food insecurity } \\
\hline $\begin{array}{l}\text { Yes } \\
\text { No }\end{array}$ & $\begin{array}{c}2.61(1.94,3.49)^{\star *} \\
\text { ref }\end{array}$ & $\begin{array}{c}1.76(1.27,2.45)^{*} \\
\text { ref }\end{array}$ & $\begin{array}{c}2.40(1.81,3.17)^{\star *} \\
\text { ref }\end{array}$ & $\begin{array}{c}1.70(1.24,2.34)^{*} \\
\text { ref }\end{array}$ \\
\hline \multicolumn{5}{|l|}{ Social Isolation } \\
\hline $\begin{array}{l}\text { Yes } \\
\text { No }\end{array}$ & $\begin{array}{c}1.82(1.372 .41)^{\star *} \\
\text { ref }\end{array}$ & $\begin{array}{c}1.62(1.19,2.20)^{*} \\
\text { ref }\end{array}$ & $\begin{array}{c}1.30(1.01,1.67)^{*} \\
\text { ref }\end{array}$ & - \\
\hline $\begin{array}{l}\text { Polypharmacy } \\
3+\text { medications/day } \\
<3 \text { medications/day }\end{array}$ & $\begin{array}{l}1.37(1.03,1.82)^{*} \\
\text { ref }\end{array}$ & - & $\begin{array}{c}1.28(0.99,1.64) \\
\text { ref }\end{array}$ & $\begin{array}{c}\text { Amongst Subjects ADL Issues=Yes } \\
2.22(1.17,4.21)^{*} \\
\text { Amongst ADL Issues }=\text { No } \\
0.97(0.72,1.32)\end{array}$ \\
\hline $\begin{array}{l}\text { Unplanned weight change } \\
\text { Yes } \\
\text { No }\end{array}$ & $\begin{array}{c}1.85(1.38,2.48)^{* *} \\
\text { ref }\end{array}$ & - & $\begin{array}{c}1.27(0.97,1.66) \\
\text { ref }\end{array}$ & - \\
\hline $\begin{array}{l}\text { ADLb Issues } \\
\text { Yes } \\
\text { No }\end{array}$ & $\begin{array}{c}2.44(1.77,3.36)^{* *} \\
\text { ref }\end{array}$ & $\begin{array}{c}\text { Amongst Whites } \\
4.92(2.04,11.84)^{*} \\
\text { Amongst Blacks } \\
0.86(0.50,1.48) \\
\text { Amongst Hispanics } \\
1.83(1.05,3.20)^{*}\end{array}$ & $\begin{array}{c}2.45(1.78,3.37)^{* *} \\
\text { ref }\end{array}$ & $\begin{array}{l}\text { Varies by Race/Ethnicity and } \\
\text { Polypharmacy }\end{array}$ \\
\hline
\end{tabular}


Table 3

Analysis of Subjects Who Would Benefit from Oral Nutritional Supplementation (ONS) by Predictor Group

\begin{tabular}{|c|c|c|c|}
\hline Predictor Group & $\begin{array}{c}\text { Total N }(\%) \text { of Participants in } \\
\text { Predictor Groupa }\end{array}$ & $\begin{array}{c}\text { N }(\%) \text { of Participants in Predictor } \\
\text { Group who Would Benefit from } \\
\text { ONSb }\end{array}$ & $\begin{array}{c}\text { N }(\%) \text { of Participants in } \\
\text { Predictor Group to Target for } \\
\text { ONS Interventionc }\end{array}$ \\
\hline Social Isolation & $481(48.24 \%)$ & $310(64.45 \%)$ & $266(55.30 \%)$ \\
\hline High school or less & $398(40.08 \%)$ & $296(74.37 \%)$ & $257(64.57 \%)$ \\
\hline Poverty & $298(29.92 \%)$ & $229(76.8 \%)$ & $204(68.46 \%)$ \\
\hline ADLd Issues & $207(20.78 \%)$ & $161(77.78 \%)$ & $131(63.29 \%)$ \\
\hline Polypharmacy & $146(14.56 \%)$ & $120(82.19 \%)$ & $93(63.70 \%)$ \\
\hline $3+$ drinks per day & $48(4.8 \%)$ & $29(60.42 \%)$ & $26(54.17 \%)$ \\
\hline
\end{tabular}

lower levels of educational attainment. Poor diet quality was more common in men.

Table 2 provides the predictive modeling results for 'inadequate dietary intake' and 'poor diet quality.' Overall, inadequate dietary intake was higher in participants reporting food insecurity $(\mathrm{P}=0.0007)$ and social isolation $(\mathrm{P}=0.0019)$ compared to those who did not. Among non-Hispanic White participants, inadequate nutritional intake was more common in those who did not attend college $(\mathrm{P}<0.0001)$ compared to those that attended at least some college. While this association is directionally similar amongst non-Hispanic Black and Hispanic participants, it did not achieve statistical significance. Compared to those who did not have limitations in ADLs, having ADL limitations was associated with inadequate intake amongst non-Hispanic Whites $(\mathrm{P}=0.0004)$ and Hispanics $(\mathrm{P}=0.0302)$, but not amongst non-Hispanic Black participants $(\mathrm{P}=0.5922)$.

Poor Diet Quality was also higher in participants with food insecurity $(\mathrm{P}=0.0010)$ and in those who reported consumption of 3 or more alcoholic drinks per day $(\mathrm{P}=0.0175)$. Specifically, poor diet quality was more common in women $(\mathrm{P}<0.0001)$ and men $(\mathrm{P}=0.0209)$ who did not attend college versus those who did, with college attendance being over two times more protective in men compared to women. Amongst participants without ADL limitations, poor diet quality was more common in non-Hispanic Black $(\mathrm{P}=0.0061)$ and Hispanic $(\mathrm{P}<0.0001)$ participants compared to non-Hispanic Whites. Amongst those who had ADL limitations, poor diet quality was more common in participants who claimed to take 3 or more medications per day $(\mathrm{P}=0.0150)$.

In total, 585 participants $(58 \%)$ reported either inadequate dietary intake or poor diet quality; thereby meeting the pre-defined criteria for requiring ONS. Of these 585, only 73 participants $(13 \%)$ had reported consuming ONS in the past 6 months. Table 3 lists the predictor groups that could benefit most from ONS. Groups to target with ONS therapy include those reporting: social isolation, lower levels of educational attainment, food insecurity, ADL limitations, polypharmacy, or those who drink three or more drinks per day. The percentage of participants in these groups who met the criteria as someone who would benefit from ONS but who had not recently consumed ONS were 55\%, $65 \%, 68 \%, 63 \%, 64 \%$, and $54 \%$ respectively.

\section{Discussion}

Based upon results of the DETERMINE Checklist administered by telephone survey, this study demonstrated that social isolation, less educational attainment, low income, heavy daily alcohol intake, compromised ADL, and polypharmacy were significant independent predictors for inadequate dietary intake and/or poor diet quality among an ethnically diverse, predominantly female community sample. Although these results are consistent with existing literature (5, $6,19-21)$, what is perhaps more interesting in our study is that so few participants in these predictor groups who could potentially benefit from ONS reported to be consuming ONS. This finding reveals a large group who could benefit most from this simple and cost-effective intervention $(15,22)$.

Poor diet quality and inadequate dietary intake are common themes amongst older community-dwelling adults. In 2015, Borg et al. (23) published a metaanalysis of 44 trials in Western countries in communitydwelling older adults with a pooled sample size of 14,419 participants comparing energy and macronutrient intake against normal reference values. The average energy intake was approximately $13 \%$ below the estimated average requirement of 2,450 kcals/day. In general, the oral diets of these older participants were below the acceptable macronutrient distribution ranges (AMDR) for carbohydrates, on the lower end of the AMDR for protein, and on the higher end for fat. These diets were $3 \%$ above the upper acceptable range for saturated fat 
and low in mono- and poly-unsaturated fats. Vitamin and mineral intake is low in older adult diets as well. In one study (19) of 345 elderly homebound Georgians, 81\% had intakes deficient in magnesium, $94 \%$ in vitamin $\mathrm{E}$, and $51 \%$ in zinc. Perhaps more alarming was that $>95.6 \%$ had deficient calcium intake and almost every participant reported inadequate vitamin D intake. In this study, skipping breakfast alone was associated with deficient energy intake as well as inadequate intake of 12 essential nutrients.

Studies exploring the effects of ONS on clinically relevant outcomes in older adults are abundant. The National Collaborating Center for Acute Care (in United Kingdom) performed a series of meta-analyses (24) exploring the pooled effects of randomizing hospital and community-dwelling subjects to receive proprietary ONS versus standard care. Randomization to receive ONS was found to significantly decrease the risk of mortality and complications, hospital length of stay, and increased weight gain. In addition, ONS has also been found to play a vital role in preventing hospital readmissions. In 2013, Stratton et al. performed a meta-analysis (25) that found a $41 \%$ reduced odds of hospital readmission amongst older adults using ONS in addition to standard care as compared to controls receiving only standard care. Further, adherence to ONS therapy in older individuals appears to be met with minimal resistance. A metaanalysis (26) of 32 randomized controlled trials and 14 non-randomized studies was performed to confirm compliance to ONS regimens. Overall pooled compliance in community settings was $80.9 \%$. The mean age of the study participants overall (hospital and communitydwellers combined) was 74 years.

Despite the current evidence supporting the positive impact ONS has on various health outcomes for at-risk individuals, very few who might benefit from ONS are actually consuming ONS. In our study, of the 58\% of participants classified as individuals who would benefit from ONS due to their poor dietary patterns, only approximately $12 \%$ had reported consuming an ONS in the past 6 months. These findings imply that registered dietitians and other healthcare professionals, given their patient's dietary needs, should target their nutrition education for ONS supplementation towards the key Predictor Groups identified in this study as they are the most likely to have inadequate dietary intake and poor diet quality. These results also highlight the importance of nutrition screening and education by primary care clinicians in these populations. It also highlights the DETERMINE Checklist as a valuable tool for identifying vulnerable individuals according to specific answers provided. The information gathered through the DETERMINE Checklist may assist clinicians in mapping the initial landscape of contextual factors that influence the dietary patterns of the at-risk populations. Therefore, efforts should be made towards further understanding these contextual factors and providing nutrition education and ONS that could be beneficial to supplement dietary inadequacies in this population.

Our study had several limitations, which are commonly reported for survey study designs. First, the cross-sectional design of our study precludes causal inference for any of the reported associations. Second, participants without either a landline or a cell phone with a Chicago area code were excluded from the survey. To the extent to which these excluded persons differed from our included participants, our study may be vulnerable to coverage bias. Third, we had a large percentage of non-responders, leading to possible non-response error. Participants who did not respond may differ meaningfully from those who did, inadvertently omitting an important portion of our target population from our analysis. Regardless of these limitations, this study included a large sample size of a multi-ethnic group of participants and the use of a professional survey research laboratory and interviewing service to assemble and administer the survey. Another strength of this study is the use of the DETERMINE Checklist as a set of domains for predicting inadequate intake and poor diet quality rather than as a weighted score. This methodology makes use of the simple strengths of the tool while bypassing the validity issues encountered in other studies $(7,18,27)$. The findings generated from this analysis could inform the designing and tailoring of future nutrition-focused interventions that could improve the nutritional outcomes of the older adult population at nutritional risk living in different community settings.

\section{Conclusions}

Inadequate dietary intake and/or poor diet quality are highly prevalent in community-dwelling older adults with social isolation, lower levels of educational attainment, food insecurity, ADL concerns, polypharmacy, and high alcohol intake. These adults may benefit from but are mostly not consuming ONS. Ensuring both the quality and quantity of their oral intake represents a tangible method to potentially treat or even prevent nutritional decline amongst older communitydwelling adults. It would be helpful to understand more about potential contextual factors in the lives of older adults, such as limited social support, poor access to healthful food options, limited food purchasing and preparation skills, depression, and others that place them at nutrition risk. Future research is needed to further identify specific barriers to proper nutritional support in this population and the potential for successful nutritionrelated interventions to supplement their dietary inadequacies.

Funding Disclosure: This study was funded by a grant from Abbott Nutrition (\#HA28). I. Farrar, M. Fitzgibbon, and P. Sheean received salary support from Abbott Nutrition. S. Sulo and J. Partridge are employees of Abbott Nutrition.

Conflicts of Interest: Jamie Patridge and Suela Sulo receive a salary and stock from Abbott. 
Ethical standards: This study was conducted according to the guidelines laid down in the Declaration of Helsinki and all procedures involving human subjects were approved by the University of Illinois at Chicago and Loyola University Chicago Institutional Review Boards. Verbal informed consent was obtained from all subjects. Verbal consent was witnessed and formally recorded.

\section{References}

1. Posner BM, Jette AM, Smith KW, Miller DR. Nutrition and health risks in the elderly: the nutrition screening initiative. Am J Public Health 1993;83(7):972-8.

2. Gunduz E, Eskin F, Gunduz M, Bentli R, Zengin Y, Dursun R, Icer M, Durgun HM, Gurbuz H, Ekinci M, et al. Malnutrition in Community-Dwelling Elderly in Turkey: A Multicenter, Cross-Sectional Study. Med Sci Monit 2015;21:27506. doi: 10.12659/MSM.893894.

3. Feldblum I, German L, Castel H, Harman-Boehm I, Bilenko N, Eisinger M, Fraser D, Shahar DR. Characteristics of undernourished older medical patients and the identification of predictors for undernutrition status. Nutr J 2007;6:37. doi: 10.1186/1475-2891-6-37.

4. Favaro-Moreira NC, Krausch-Hofmann S, Matthys C, Vereecken C, Vanhauwaert E, Declercq A, Bekkering GE, Duyck J. Risk Factors for Malnutrition in Older Adults: A Systematic Review of the Literature Based on Longitudinal Data. Advances in nutrition 2016;7(3):507-22. doi: 10.3945/ an.115.011254.

5. Boulos C, Salameh P, Barberger-Gateau P. Social isolation and risk for malnutrition among older people. Geriatr Gerontol Int 2017;17(2):286-94. doi: 10.1111/ggi.12711.

6. Locher JL, Ritchie CS, Roth DL, Baker PS, Bodner EV, Allman RM. Social isolation, support, and capital and nutritional risk in an older sample: ethnic and gender differences. Soc Sci Med 2005;60(4):747-61. doi: 10.1016/j. socscimed.2004.06.023.

7. Sahyoun NR, Jacques PF, Dallal GE, Russell RM. Nutrition Screening Initiative Checklist may be a better awareness/educational tool than a screening one. J Am Diet Assoc 1997;97(7):760-4. doi: 10.1016/S00028223(97)00188-0.

8. Kantoch A, Wielek J, Gryglewska B, Grodzicki T. Nutritional and Functional Status in Newly Hospitalized Older Patients Who are Not Underweight. J Nutr Gerontol Geriatr 2017;36(2-3):111-20. doi: 10.1080/21551197.2017.1377138.

9. Gariballa S, Forster S. Malnutrition is an independent predictor of 1-year mortality following acute illness. Br J Nutr 2007;98(2):332-6. doi: 10.1017/ S0007114507701708

10. Kassin MT, Owen RM, Perez SD, Leeds I, Cox JC, Schnier K, Sadiraj V, Sweeney JF. Risk factors for 30-day hospital readmission among general surgery patients. Journal of the American College of Surgeons 2012;215(3):322-30. doi: 10.1016/j.jamcollsurg.2012.05.024.

11. Mudge AM, Kasper K, Clair A, Redfern H, Bell JJ, Barras MA, Dip G, Pachana NA. Recurrent readmissions in medical patients: a prospective study. J Hosp Med 2011;6(2):61-7. doi: 10.1002/jhm.811.

12. Goisser S, Schrader E, Singler K, Bertsch T, Gefeller O, Biber R, Bail HJ, Sieber CC, Volkert D. Malnutrition According to Mini Nutritional Assessment Is Associated With Severe Functional Impairment in Geriatric Patients Before and up to 6 Months After Hip Fracture. J Am Med Dir Assoc 2015;16(8):661-7. doi: 10.1016/j.jamda.2015.03.002.
13. Koren-Hakim T, Weiss A, Hershkovitz A, Otzrateni I, Grosman B, Frishman S, Salai M, Beloosesky Y. The relationship between nutritional status of hip fracture operated elderly patients and their functioning, comorbidity and outcome. Clin Nutr 2012;31(6):917-21. doi: 10.1016/j.clnu.2012.03.010.

14. Zuliani G, Romagnoni F, Volpato S, Soattin L, Leoci V, Bollini MC, Buttarello M, Lotto D, Fellin R. Nutritional parameters, body composition, and progression of disability in older disabled residents living in nursing homes. J Gerontol A Biol Sci Med Sci 2001;56(4):M212-6.

15. Elia M, Normand C, Laviano A, Norman K. A systematic review of the cost and cost effectiveness of using standard oral nutritional supplements in community and care home settings. Clin Nutr 2016;35(1):125-37. doi: 10.1016/j.clnu.2015.07.012.

16. Hamirudin $\mathrm{AH}$, Charlton $\mathrm{K}$, Walton $\mathrm{K}$. Outcomes related to nutrition screening in community living older adults: A systematic literature review. Arch Gerontol Geriatr 2016;62:9-25. doi: 10.1016/j.archger.2015.09.007.

17. Lyons BP. Nutrition education intervention with community-dwelling older adults: research challenges and opportunities. J Community Health 2014;39(4):810-8. doi: 10.1007/s10900-013-9810-x.

18. Sinnett S, Bengle R, Brown A, Glass AP, Johnson MA, Lee IS. The validity of Nutrition Screening Initiative DETERMINE Checklist responses in older Georgians. J Nutr Elder 2010;29(4):393-409. doi: 10.1080/01639366.2010.521031.

19. Sharkey JR, Branch LG, Zohoori N, Giuliani C, Busby-Whitehead J, Haines PS. Inadequate nutrient intakes among homebound elderly and their correlation with individual characteristics and health-related factors. The American journal of clinical nutrition 2002;76(6):1435-45.

20. Walker D, Beauchene RE. The relationship of loneliness, social isolation, and physical health to dietary adequacy of independently living elderly. J Am Diet Assoc 1991;91(3):300-4.

21. Weimer JP, United States. Department of Agriculture. Economic Research Service. Factors affecting nutrient intake of the elderly. Washington, D.C. (1800 M. Street NW Washington 20036-5831): United States Department of Agriculture, Economic Research Service, 1998.

22. Philipson TJ, Snider JT, Lakdawalla DN, Stryckman B, Goldman DP. Impact of oral nutritional supplementation on hospital outcomes. Am J Manag Care 2013;19(2):121-8.

23. ter Borg S, Verlaan S, Mijnarends DM, Schols JM, de Groot LC, Luiking YC. Macronutrient Intake and Inadequacies of Community-Dwelling Older Adults, a Systematic Review. Ann Nutr Metab 2015;66(4):242-55. doi: $10.1159 / 000435862$

24. Edtion ed. Nutrition Support for Adults: Oral Nutrition Support, Enteral Tube Feeding and Parenteral Nutrition. London, 2006.

25. Stratton RJ, Hebuterne X, Elia M. A systematic review and meta-analysis of the impact of oral nutritional supplements on hospital readmissions. Ageing Res Rev 2013;12(4):884-97. doi: 10.1016/j.arr.2013.07.002.

26. Hubbard GP, Elia M, Holdoway A, Stratton RJ. A systematic review of compliance to oral nutritional supplements. Clin Nutr 2012;31(3):293-312. doi: 10.1016/j.clnu.2011.11.020.

27. Vieira LS, Assuncao MCF, Schafer AA, Santos I. Validity assessment of the nutrition screening initiative checklist in older adults. Clin Nutr ESPEN 2016;15:16-20. doi: 10.1016/j.clnesp.2016.05.002. 